\title{
PERSONAGENS NEGRAS NA LITERATURA INFANTOJUVENIL: ANALISANDO A FIGURA DA PRINCESA NEGRA NO CONTO PRETINHA DE NEVE E OS SETE GIGANTES (2013) \\ BLACK CHARACTERS IN CHILDREN'S LITERATURE: ANALYZING THE FIGURE OF THE BLACK PRINCESS IN THE SHORT STORY PRETINHA DE NEVE AND THE SEVEN GIANTS (2013)
}

Resumo: Este artigo toma como objeto de estudo o conto Pretinha de Neve e os Sete Gigantes (2013) e tem como objetivo analisar a construção da imagem da personagem principal da obra, a qual é uma princesa negra. A análise considera tanto o texto verbal quanto as ilustrações.

Abstract: This article takes as its object of study the short story Pretinha de Neve and the Seven Giants (2013) and aims to analyze the construction of the image of the main character of the work, which is a black princess. The analysis considers both the verbal text and the illustrations.

Palavras-chave: personagem; princesa negra; ilustrações.

Keywords: character; black princess; illustrations.

\section{Considerações iniciais}

O conto Pretinha de Neve e os Sete Gigantes (2013) apresenta uma proposta de ruptura com o imaginário ocidental acerca da imagem da princesa, uma vez que longe de apresentar essa personagem por meio de uma imagem que corresponde à sua representação na cultura europeia, traz uma princesa negra, que foge aos traços tradicionais internalizados para esse arquétipo no inconsciente coletivo brasileiro.

Nessa narrativa é perceptível também um destaque para a construção intertextual da obra, para seu caráter paródico e, portanto, para o confronto entre imaginários no que concerne à figura da princesa, explorando a presença de personagens negras na realeza, além de explorar bastante a ilustração como elemento decisivo para a presença positiva do negro na obra.

Em face disso, o objetivo desse trabalho é analisar como se constrói a imagem da personagem princesa a partir do conto Pretinha de Neve e os Sete Gigantes (2013), o qual traz uma princesa negra como protagonista, promovendo uma abordagem positiva do negro.

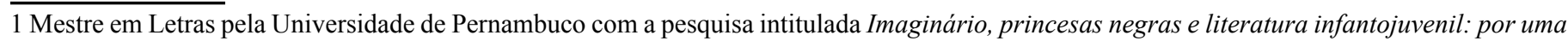
educação literária antirracista no $6^{\circ}$ ano do ensino fundamental. 


\section{Literatura infantojuvenil e personagens negras}

A literatura infantojuvenil teve origem na Europa, entre os séculos XVII e XIX e, desde seu surgimento, já era possível notar representações que continham forte teor racista. Segundo Oliveira (2007), desde os contos dos Irmãos Grimm já se podia notar a negatividade que permeava a elaboração das personagens negras.

Lajolo e Zilberman (2007), por sua vez, afirmam que a literatura infantojuvenil brasileira sofreu muita influência das narrativas europeias, tanto que a maior parte das histórias contadas no Brasil advém do folclore europeu e não absorveram quase nenhuma peculiaridade local, ou seja, não incorporaram elementos das culturas negra e indígena.

Nessa literatura, a personagem negra começou a aparecer a partir da década de 1930, pois antes era ausente e quando aparecia nem sequer falava (OLIVEIRA, 2007). Mesmo a partir desse período em que as personagens negras passaram a integrar o enredo, as narrativas infantojuvenis continuaram perpassadas pela ideia de branqueamento.

Com isso, as representações da pessoa negra no discurso literário infantojuvenil consistiam em imagens de caráter estereotipado, eurocêntrico e, muitas vezes, racistas. A antropóloga e escritora Heloísa Pires Lima, em estudo recente, ainda tece várias críticas a esse respeito; para ela, a figura do negro continua sendo objeto de estereotipia e de um leque resumido de representações, aparecendo, quase sempre, como perdedor social. Sobre isso, ela afirma que:

No caso brasileiro, repertórios africanos ficaram bastante desconhecidos, verdadeiros tabus evitados de qualquer forma. Resultado, o padrão africano ficou bastante restrito em espessura humana. A origem europeia de personagens é representada numa gama psicológica versátil e em posições sociais as mais variadas. Bonzinhos, malvados, apaixonados, tristes, príncipes, mendigos, enfim, abarcam uma representação ampla como espelho da realidade. Já a origem africana foi fixada quase unicamente como perdedora social. Tal como a África das mídias contemporâneas, prevalece a dor, o sofrimento, a passividade, inferioridade política entre outras imagens. Deste modo, o comparativo com os demais mundos é uma premissa mantenedora de hierarquias para o imaginário no recorte das origens continentais. O problema não está em existir a representação contemplada, e sim na insistência em não ampliá-la. (LIMA, 2018, p. 36)

Destarte, é perceptível uma dicotomia na forma como brancos e negros são representados no discurso literário, evidenciando que enquanto aqueles têm direito a múltiplas imagens, sendo retratados por meio de diferentes olhares, esses têm apenas uma imagem estática que está diretamente 
ligada a aspectos negativos, os quais contribuem para reforçar ideias de cunho racista e reforçar na literatura a visão já legitimada social e historicamente em nosso país: uma suposta superioridade branca e uma supervalorização da cultura europeia/ocidental em detrimento das culturas africanas, com vistas a contemplar somente uma parte dos elementos culturais que fazem do Brasil um país multicultural.

Ainda pensando na dicotomia entre personagens brancas e personagens negras, Oliveira (2007) assevera que o negro era associado à ruindade e feiura, enquanto os brancos ligavam-se aos ideais de beleza e benevolência. Além disso, eram recriadas as relações entre senhores e escravos, com predominância das dualidades branco-algoz, negro-vítima.

As imagens mais recorrentes de personagens negras na literatura infantojuvenil, de acordo com Lima (2005), têm sido as seguintes: escravo, grotesco, frágil, perdedor, passivo, bobo e desajeitado. Sua imagem aparece também ligada à falta de limpeza e à burrice, além de que, se a personagem for mulher, normalmente será retratada como empregada doméstica. Tudo isso torna possível discordar de Nelly Novaes Coelho, quando esta afirma que "na (literatura) infantil mesclam-se, em pé de igualdade, personagens das várias raças; e também é abordado frontalmente o problema do racismo, como das grandes injustiças humanas e sociais" (1987, p. 10), pois mesmo que já haja algumas obras literárias cujos personagens negras são abordados com legitimidade e valorização, há ainda um grande conjunto de representações depreciativas nesse sentido.

Tradicionalmente, conforme Brookshaw, "nas histórias infantis a negritude era associada ao mal e os que faziam mal eram negros" (1983, p. 13), bem como era comum o negro ocupar o lugar de narrador, fosse reforçando a imagem de preto velho, das amas-de-leite ou das cozinheiras negras, imagens essas que são representativas de estereótipos e que contribuíram "apenas para justificar a submissão de que (os negros) são vítimas" (LAJOLO e ZILBERMAN, p. 7).

Dessa forma, ao invés de promover uma imagem positiva da população negra, esses tipos de representações "reforçam estereótipos de subserviência, inferioridade, passividade, e autopercepção negativa por parte dos personagens negros e, ao contrário, delineia os brancos como aqueles que são superiores, têm altivez, autoestima e o poderio social" (OLIVEIRA, p. 5), indo de encontro ao que se espera de um país cuja cultura é significativamente marcada por traços africanos e carece desse reconhecimento para aprender a lidar com a diferença.

Nessa perspectiva, a personagem negra deve assumir lugares de destaque nas obras infantojuvenis, pois consoante Oliveira (2007), a população negra deve ser valorizada através da caracterização das personagens, as quais devem ser delineadas positivamente pelos seus traços negros numa tentativa de ressignificar o conceito de beleza e promover a valorização da cosmovisão africana. Em outras palavras, são necessárias obras que discutam a questão racial e cultural africana de maneira legítima, indo "além da marca de perdedor social que fica à mercê de representações sociais hediondas" (LIMA, 2010, p. 49). Nessa direção, pensar a imagem da princesa negra em obras 
contemporâneas abre um leque de possibilidades acerca dessas representações positivas do negro na literatura infantojuvenil.

\section{A imagem da princesa como personagem}

Uma das figuras mais recorrentes nos contos de fadas é a princesa, personagem em torno da qual giram praticamente todas essas narrativas. A imagem a qual essa personagem é/foi associada ao longo do tempo pela cultura ocidental é a seguinte: "são lindas, geralmente de pele muito clara e de cabelos loiros" (ROCHA, 2009, p. 27), visão bem semelhante à de Correia (2010, p. 9) segundo a qual as princesas "surgem como um modelo hegemônico de feminilidade: etnia branca, jovem, heterossexual, magra, bonita e dócil". Assim sendo, podemos perceber que o ideal de beleza se liga a um imaginário eurocêntrico, no qual o poder e o belo não se associam a pessoas que não sejam brancas. Desse modo, a associação princesa/poder/beleza/brancura instaura uma sobreposição dos valores europeus em detrimento de quaisquer outros.

Essa sobreposição valorativa que favorece a cultura eurocêntrica no que concerne à figura da princesa se disseminou no Brasil através dos clássicos da literatura infantojuvenil europeia, a qual se expandiu pelas Américas a partir do século XVIII, representada, sobretudo, pelos Irmãos Grimm. Foi a partir dessa expansão que se cristalizou a imagem da princesa como sendo um ser tipicamente europeu, imagem essa queainda é mantida pelos meios de comunicação no Brasil, elucidandoque

o padrão de beleza ainda é o de um corpo esguio, etnocentricamente valorizado, a ser olhado, desejado e comprado. Trata-se de modelos magérrimas, altas, de pele clara e, na maioria das vezes, de cabelos lisos. São essas as heroínas modernas (SOUSA, 2009, p. 58).

Diante disso, se fazem necessárias algumas observações: 1) o Brasil é um país cuja principal marca é a diversidade étnica; 2) diante dessa diversidade, é questionável a presença de um único padrão de representação da figura das princesas; 3) os outros padrões (aqueles que representam culturas e povos que contribuíram para a formação da diversidade brasileira, mas distinguem-se do modelo europeu) também fornecem modelos de representação para essas imagens femininas, porém essas representações são extremamente escassas. Esses três pontos tornam possível afirmar que houve, em nosso país, uma espécie de apagamento das imagens que constituem o modelo de princesa oriundo das outras matrizes culturais que constituem a diversidade do nosso país, dentre elas as imagens das princesas africanas.

A imagem dessas princesas africanas foi (e continua sendo) apagada do imaginário brasileiro, ajudando a fortalecer uma visão cada vez mais restrita acerca de África, haja vista que: 
As imagens ainda hoje predominantes e que povoam as mídias e também o imaginário brasileiro são as das famosas heroínas europeias. Não é novidade que as narrativas de heroínas brasileiras são marcadas por um investimento na invisibilidade ou na estereotipia das heroínas negras brasileiras. (SOUSA, p.59)

Assim, as heroínas são branqueadas porque o conceito de princesa não está ligado à mulher negra africana/afro-descendente, pois ela não condiz com o modelo princesa/poder/beleza/brancura já instaurado pelo imaginário ocidental, uma vez que as relações negritude/poder e negritude/beleza ainda são vistas como exceções, dificultando a associação negritude/princesa, já que ser princesa exige, obrigatoriamente, ter poder e beleza, algo não concedido a alguém de pele negra do ponto de vista da cultura ocidental, pois, conforme Joice Berth (2018), as mulheres negras integram os grupos subalternizados dentro da pirâmide social, sendo vítimas de grande invisibilidade.

Em face disso, podemos perceber que as referências que possuímos acerca do que é ser princesa ligam-se quase que exclusivamente à Europa, não permitindo a associação dessa figura feminina ao continente africano, já que as imagens que temos sobre África são advindas de uma visão limitadora e excludente, sempre associando esse continente à negatividade e não permitindo compreender que "nem todas as princesas são as dos contos de fadas da Europa, a bela, gloriosa e deslumbrante irmã" e que "a África, por exemplo, deu ao mundo princesas famosas, como Nefertiti, [...] e Cleópatra" (ROCHA, p. 27), e que se elas não são conhecidas como negras e africanas, é devido ao branqueamento de suas imagens na mídia e no cinema.

Nesse contexto, se no Brasil não há diversidade no que diz respeito à imagem da figura da princesa, é porque esse país ainda não se permitiu ampliar as possibilidades de representação, prendendo-se a um imaginário limitador e restrito no que se refere ao continente africano. É necessário que a imagem da princesa negra, assim como a princesa branca, tenha aceitação e legitimidade.

\section{Uma princesa negra na literatura infantojuvenil: Pretinha de Neve}

Nessa narrativa ocorre uma inversão de imaginário já no título, pois é evidente que ele foi criado a partir de outro título bem conhecido, Branca de Neve e os Sete Anões. Nesse caso, ocorre a substituição dos elementos principais que o constituem por outros que sugerem esse novo imaginário: o termo Branca é substituído por Pretinha, apontando para a mudança de protagonista; já o termo anões é substituído por gigantes, consolidando a inversão de papéis ocorrida nesta adaptação.

O título, elemento que segundo Linden (2011) se relaciona com a imagem da capa, dando origem a um vínculo texto-imagem, já fornece ao leitor pistas acerca da proposta da narrativa, pois a 
partir dele já é possível perceber que a princesa branca foi substituída por uma princesa negra, como se pode ver na imagem da capa:

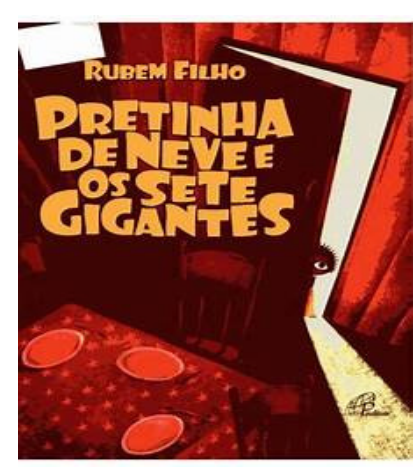

Figura 1 - Capa do livro Pretinha de Neve e os Sete Gigantes Fonte: PNSG, 2013

O fato de a garota da imagem não aparecer por completo, se encontrando amparada pela porta, sugere uma espécie de licença para romper com os estereótipos vigentes na sociedade, como se estivesse perguntando: "Pode uma princesa ser negra?", interpretação que se justifica pelo fato de que os estereótipos criados em torno da pessoa negra tem sobrevivido ao longo do tempo, uma vez que "no Brasil [...] o preconceito contra o negro tem sido e ainda é um dos mais arraigados em nossa experiência histórica em virtude de séculos de escravidão" (BROOKSHAW, p. 12).

Outro ponto que chama a atenção é que a própria ilustração já sinaliza as inversões propostas no texto: é uma princesa pequena atrás de uma grande porta, ou seja, desde o início já fica sugerido que os anões serão gigantes — já que a porta da casa deles é grande — e que a princesa será bem pequena, tendo em vista o tamanho dela comparada aos outros elementos da imagem, bem como o sufixo presente em seu nome.

Além da substituição de nomes no título, outro aspecto que permite associar a menina da capa à ideia de princesa é a semelhança entre sua vestimenta e a famosa roupa da personagem Branca de Neve nas imagens veiculadas pela Disney, como se pode ver:

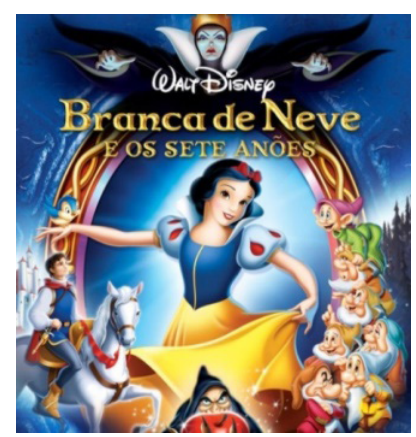

Figura 2 - Cartaz publicitário do filme Branca de Neve e os Sete Anões, 1937

Fonte: Site da Disney Fandom ${ }^{2}$

2 https://dublagempedia.fandom.com/pt-br/wiki/Branca_de_Neve_e_os_Sete_An\%C3\%B5es_(1937) > Acesso em: 25, Ago. 2019. 
Assim sendo, é esse elemento de sua indumentária que insinua o lugar social ocupado por ela na narrativa, evidenciando que a capa "não tira o impacto do efeito, e sim reforça a inquietação gerada pelo título" (LINDEN, p. 57), pois ambos os elementos contribuem para que o leitor relacione a personagem a uma princesa, promovendo uma espécie de transgressão no que tange ao imaginário ocidental sobre a princesa. Na capa, a figura que aparece pode ser abordada mediante suas características físicas: cabelos negros, crespos e curtíssimos bem como a pele negra, elementos que embora não delimitem de maneira estanque a noção de pertencimento étnico-racial - uma vez que esse conceito liga-se a construções culturais, conforme atestam Kaercher e Dalla Zen (2012) - configuram-se como traços que, num primeiro momento, sinalizam essa pertença. No que concerne ao enredo da narrativa, é importante salientar que não se trata de uma obra que explicita a discussão étnico-racial, mas que busca "reverter a histórica invisibilidade da etnia negra na composição das personagens centrais dos livros" (KAERCHER; DALLA ZEN, p. 186), povoando toda a história de personagens negras a fim de dar-lhes visibilidade, espaço para uma representação positiva. Pretinha de Neve é uma menina que vive na África com a mãe e o padrasto, o rei. O enredo dessa narrativa é simples e, em certa medida, engraçado, além de apresentar tessitura bastante palimpséstica, uma vez que incorpora elementos de várias narrativas europeias além de basear-se, sobretudo, em Branca de Neve e os Sete Anões.

Nesse conto, o que se vê é uma narrativa europeia ganhando ares africanos, pois no momento da seleção dos elementos que constituiriam a obra optou-se por selecionar personagens negras, deixando ausentes as personagens brancas. Nesse caso, optou-se por levar em conta a diversidade étnico-racial, a valorização da pessoa negra.

Algo que merece atenção é que enquanto Pretinha é uma personagem que rompe com os estereótipos de gênero, não se pode ignorar que o texto também reproduz o modelo colonial heteronormativo no que diz respeito à relação das personagens rei e rainha. Ou seja, a relação entre esse casal acaba reforçando o modelo nuclear branco e colonial, evidenciando o quanto é difícil esse desprendimento das tradições europeias.

No primeiro parágrafo do conto, em tom didático, típico da literatura infantojuvenil, o narrador situa o leitor acerca da ambientação narrativa: "Vocês sabiam que na África também cai neve? Isso acontece no monte Kilimanjaro, que fica no coração do continente. Ele é muito, muito alto, e lá em cima sempre faz frio" (FILHO, p.5). Diferente da maioria dos contos de fadas, em que a localização do ambiente é dada de forma imprecisa, indefinida, essa narrativa é geograficamente situada em um lugar específico, o qual não se localiza no continente europeu, mas em África, uma vez que a história é vivenciada no monte Kilimanjaro, o pico mais alto do território africano.

Nesse sentido, torna-se possível uma ampliação das imagens que constituem o imaginário sobre África, já que é apresentada uma nova versão desse continente a partir do Monte Kilimanjaro, indo de encontro ao que afirma Oliva (2009) sobre as imagens sobre África, a qual é vista como 
puramente desértica e extremamente quente, sempre vinculada à ideia de exotismo ou escravidão.

Nesse contexto, a figura da princesa aparece pela primeira vez interligada a um cenário africano, afastando a imagem da pessoa negra dos estereótipos inferiorizantes que normalmente são atribuídos a ela, ou seja, tentando reverter um quadro no qual "a ascendência africana estava invisível ou desqualificada, sem pudor, para os jovens" (LIMA,2018, p. 34). Assim, a imagem da princesa negra começa a funcionar como uma representação simbólica na qual o arquétipo da princesa materializase, pautando-se agora numa concepção de princesa advinda de outro imaginário e promovendo um afastamento das representações em que "a figura da heroína ainda é permeada por aquela imagem ocidentalizada, sub-representando as guerreiras negras, sejam elas históricas, reais, fictícias e/ou mitológicas" (SOUSA, p. 59).

Nesse mesmo trecho já tem início a figuração da personagem Pretinha, pois ao definir a ambientação da história, o narrador define também uma característica da personagem: ela é africana. Sendo assim, seu nome não é Pretinha de Neve por ter a pele branca como a neve, assim como a heroína do conto dos Irmãos Grimm, mas sim porque ela vive num local onde há muita neve. Nesse sentido, a expressão de Neve estabelece uma ideia de pertencimento, de ser daquele lugar, não apresentando nenhuma relação com a cor da pele da personagem.

A imagem que ilustra esse fragmento verbal estabelece com ele uma relação de associação na perspectiva de Linden (2011), uma vez que texto e imagem coexistem numa mesma página. Além disso, imagens e palavras mantêm uma relação de colaboração, uma vez que a imagem complementa o que está escrito, fornecendo outros elementos que são úteis à interpretação. Vejamos:

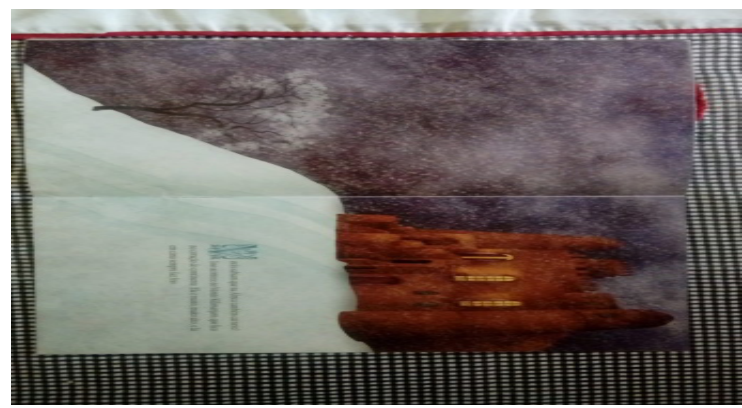

Figura 3 - Castelo onde vive Pretinha de Neve Fonte: PNSG, p. 4-5

A presença do castelo na ilustração reforça a chance de existência de uma princesa na África, pois ainda que o castelo da história apresente-se baseado em moldes europeus, devido ao caráter paródico da narrativa, por si só a presença desse tipo demoradia já sugere a possibilidade de uma realeza africana, associando a hegemonia às personagens negras que ali vivem.

Após essa primeira página, texto e imagem passam a aparecer alternadamente, ou seja, uma página de texto, outra de imagem. Esse aspecto chama atenção para o fato de que o enredo verbal 
funciona perfeitamente sem a sequência de imagens, no entanto, são as ilustrações que promovem a discussão acerca da representatividade negra positiva, haja vista que em nenhum momento o texto verbal faz menção a isso. Nota-se, então, a importância da representação verbo-icônica citada por Wunemburguer (2007), pois analisar apenas a parte escrita não daria conta de mostrar que o conto em questão subverte os "enredos racialistas, comumente extensões das representações das populações colonizadas" (LIMA, 2018, p.102).

A descrição verbal da personagem Pretinha de Neve é realizada logo no início da narrativa, configurando um retrato, uma vez que a instância narrativa caracteriza-se pela voz e focalização do narrador: "O rei não gostava muito de sua enteada, que tinha crescido e era uma menininha muito espoleta, chamada Pretinha. Ela tinha mania de fazer uma pergunta atrás da outra, e ele não tinha a menor paciência para responder" (FILHO, p. 6). Nesse fragmento, a matéria descrita é de caráter psicológico, pois é perceptível que Pretinha era uma menina curiosa, agitada e sapeca. Todavia, nenhum traço físico é contemplado nessa caracterização, ficando, pois, a critério de uma leitura da ilustração. É aí que ocorre o que Carlos Reis (2018) chama de refiguração icônica, ou seja, a personagem construída linguisticamente passa a ser uma imagem, um elemento visual, ampliando o imaginário contido no texto verbal.

Nesse processo de refiguração icônica, ocorre um preenchimento de vazios, isto é, o ilustrador preenche imageticamente as lacunas deixadas pelo texto verbal, o que acaba dando margem para que ocorra a transnarratividade. Dessa forma, o contexto sociocultural - que é externo ao texto - interfere na elaboração das ilustrações, uma vez que as imagens buscam dar conta de uma demanda social: a representatividade da pessoa negra em posições favoráveis, positivas, nesse caso, na condição de realeza. Assim, as características físicas que não são contempladas no texto, são contempladas na imagem:

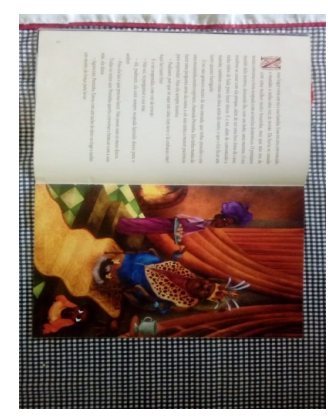

Figura 4 - Pretinha de Neve, sua mãe e seu padrasto Fonte: PNSG, p. 7

Na figura 4, as imagens do rei, da rainha e da princesa fogem do lugar-comum, pois apresentam traços que pertencem a outra cultura, outro povo diferente do europeu. As personagens são negras e suas indumentárias são características da África, divergindo das vestimentas europeias - com exceção 
de Pretinha, cujo traje marca a alusão à princesa Branca de Neve. A rainha e o rei usam cores vivas, típicas das culturas africanas; além disso, aquela tem na cabeça um turbante em substituição à coroa, a qual só é usada pelo rei e remete às máscaras africanas, pois se apresenta ornamentada por penas de animais. Já a princesa, apesar da roupa europeizada, usa miçangas nos cabelos, típico acessório africano.

Por se afastar do previsível dentro do imaginário coletivo eurocêntrico, uma vez que nesse imaginário a realeza é constituída por pessoas brancas, nesse conto é notável que a aparência física das personagens não se enquadra nos modelos pré-estabelecidos a partir do imaginário ocidental, tendo em vista que este se pauta no princípio de que os lugares hegemônicos são reservados às pessoas brancas, ao passo que às pessoas negras cabe lidar com figurações vinculadas ao simbolismo negativo da cor e do preconceito racial, como afirma Brookshaw (1983).

Pretinha, por meio de seu processo de figuração, mostra-se muito curiosa, o que se pode ver em sua conversa com o padrasto:

- Padrasto, por que aqui em cima tem neve e embaixo não? Aqui faz tanto frio.
E o rei respondia, com voz de trovão:
- Não sei, vá perguntar a sua mãe.
- Ah, padrasto, ela está sempre ocupada fazendo doces para o senhor. (FILHO, p. 6)

Todavia, as pessoas que vivem a sua volta não lhe dão muita atenção, fazendo com que a garota sinta-se solitária, algo que fica evidente no trecho seguinte: “[...] Pretinha não era uma menina feliz. Não tinha com quem brincar, nunca havia saído de casa e se sentia sozinha” (FILHO, p. 9). A solidão é o sentimento mais presente na vida dessa personagem, tanto que ela chega a conversar com o tacho de cobre da cozinha, a quem pergunta: “-Tacho de cobre, tacho de cobre, existe alguma menina mais solitária do que eu? Minha mãe está sempre ocupada e nunca me dá atenção. E o meu padrasto é muito chato" (IDEM, p. 9). Esse trecho remete à fala da madrasta do conto Branca de Neve, quando esta questiona o espelho do castelo acerca de sua beleza, a fim de ter certeza de que é a mulher mais bela do reino.

Nessa perspectiva, enquanto Pretinha questiona acerca de sua solidão, da falta de atenção por parte dos adultos, a madrasta interpela o espelho com medo de que haja uma mulher que supere sua beleza. Assim, é o diálogo com um objeto inanimado personificado - nas duas narrativas - o responsável pelo afastamento das duas princesas de seus lares, tendo em vista que devido à solidão, Pretinha fugirá do castelo, e Branca, devido à inveja de sua madrasta, acaba também por se afastar de casa, só que à força. Nesse contexto, podemos perceber que o tema central do conto Branca de Nevee os Sete Anões é alterado, pois a inveja dá lugar à solidão. 


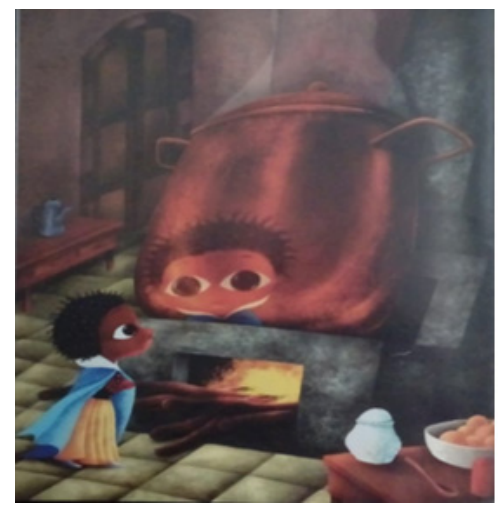

Figura 5 - Pretinha conversando com o tacho de cobre Fonte: PNSG, p. 8

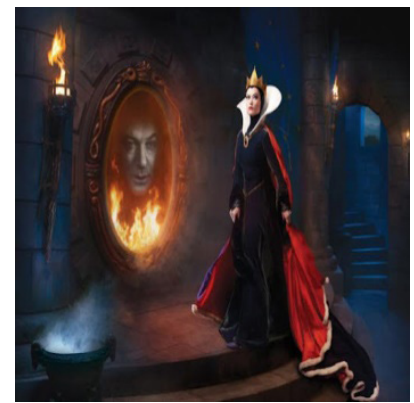

Figura 6 - Madrasta da Branca de Neve conversando com o espelho Fonte: Site Eu gordinha wordpress ${ }^{3}$

A figura 5 corresponde à ilustração do momento em que a princesa e o tacho estão conversando. Nela há um cruzamento de imaginários distintos, pois reconhecemos elementos do conto europeu ao mesmo tempo em que a personagem que protagoniza a imagem é diferente daquelas que tradicionalmente materializam o arquétipo de princesa. A maneira como Pretinha olha e dialoga com o tacho se assemelha à imagem da madrasta conversando com o espelho, à medida que há também uma diferença no modo como a pequena princesa age: com a fisionomia triste, ela busca seu reflexo no tacho, tentando estabelecer uma tentativa de encontro consigo mesma, uma tentativa de descobrir uma forma de tornar-se mais feliz. Em seguida, Pretinha de Neve decide fugir do castelo e descer do monte:

Juntou alguns doces na mochila, para o caso de sentir fome no caminho, colocou um capuz vermelho (emprestado de outra história) e foi conferir a situação. [...] Então, pé ante pé, ela saiu do castelo e começou a descer o monte, curiosamente para saber o que há fora do castelo. Andou, andou, andou e viu muitas coisas diferentes: árvores enormes, bichos diferentes, rios, flores, pássaros. Estava encantada com o que via. E como fazia calor! Isso a deixou contente, mas teve que tirar o capuz vermelho. Mas também na África nem existe lobo. Só que ela não

3 https://eugordinha.wordpress.com/2012/02/24/sua-cara-e-bonita/madrasta-branca-de-neve-e-espelho/> Acesso em: 25, Ago. 2019. 
Nesse excerto, Rubem Filho se apropria de elementos de vários outros contos tradicionais da cultura europeia para compor ações de sua personagem, não se limitando somente ao conto de Branca de Neve e os Sete Anões, com o qual estabelece um diálogo mais explícito. Dessa forma, o leitor é remetido às histórias de Chapeuzinho Vermelho e Alice no País das Maravilhas, ora de forma mais direta, ora de forma indireta. Quando o narrador diz que Pretinha de Neve "juntou alguns doces na mochila, para o caso de sentir fome no caminho" e "colocou um capuz vermelho", de imediato recupera-se o trecho em que Chapeuzinho coloca doces numa cesta para levar para sua avó, momento a partir do qual ela passa a correr perigo, situação semelhante à de Pretinha, a qual saiu do castelo sem permissão, ficando exposta a todos os perigos. Observa-se, assim, um forte predomínio da intertextualidade, confirmando que "a literatura se escreve com a lembrança daquilo que é, daquilo que foi. Ela a exprime, movimentando sua memória e a inscrevendo nos textos por meio de um certo número de procedimentos de retomadas, de lembranças e de re-escrituras" (SAMOYAULT, 2008, p. 47).

Já a curiosidade que caracteriza Pretinha faz lembrar Alice, personagem do clássico escritor britânico Lewis Carroll, que tomada por sua curiosidade acaba vivendo várias aventuras no País das Maravilhas. A princesa africana demonstra essa mesma característica quando "começou a descer o monte, curiosamente para saber o que há fora do castelo". O cenário encontrado por Pretinha longe do Monte Kilimanjaro serve como uma forma de demonstrar a diversidade presente em África, construindo um cenário totalmente diferente do anterior, o qual era chuvoso e frio.

A princesa, figurativamente, acaba sendo caracterizada como corajosa e determinada, buscando seu lugar no mundo, pois ela retira o capuz e lança-se à descoberta do novo. No que se refere ao parâmetro da valoração, essa caracterização é considerada como apreciativa, haja vista que a personagem é elaborada a partir de traços positivos. Assim, essa figura vai de encontro às representações comumente dadas às personagens negras, que segundo Maria Anória de J. Oliveira (2007) são postas, na maioria das vezes, sob a condição de antagonistas. Ou seja, o que ocorre é a reversão de um estereótipo já cristalizado no discurso literário devido ao imaginário alimentado por imagens negativas sobre o negro. 


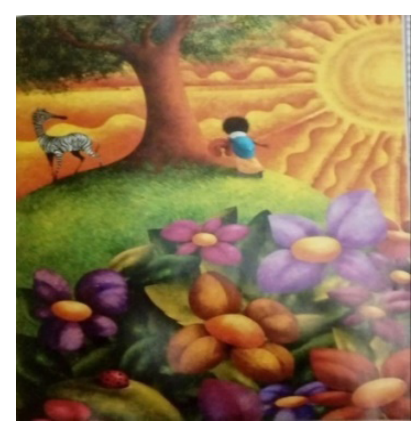

Figura 7 - Pretinha de Neve em sua fuga do castelo Fonte: PNSG, p. 11

A figura 7 ilustra o trecho anteriormente citado da narrativa e ajuda a compor o contraste entre a ambientação aí descrita e o monte Kilimanjaro, onde tem início a história. O espaço onde a princesa se encontra agora também se situa em África, todavia consiste numa paisagem bem diferente da anterior. Outro ponto que merece atenção é a imagem da zebra, típico animal da fauna africana, que pode ser associado ao trecho "na África nem existe lobo", reforçando a presença de elementos africanos em detrimento dos europeus.

Tal qual na história de Branca de Neve, Pretinha também encontra uma casa, mas diferente da casa da história dos irmãos Grimm, em que era tudo muito pequeno, no conto de Rubem Filho, a princesa africana:

Viu-se diante de uma cabana enorme! Era tão grande que nem dava para alcançar a janela e ver o que tinha lá dentro. A menina então empurrou a porta e percebeu que a cabana estava vazia. Foi entrando, devagarinho, impressionada com o tamanho das coisas: as camas, a mesa, as cadeiras, e tudo com sete lugares. Ela se sentiu como a menina daquela outra história, que tomou um líquido misterioso de uma garrafinha e encolheu. (FILHO,p. 10)

Pode-se notar, então, que a casa pequena presente na história de Branca de Neve passa a ser uma cabana enorme no conto de Rubem Filho. O mesmo acontece com todos os móveis, fazendo com que a princesa se sinta como Alice, personagem inglesa que tomou um líquido desconhecido e acabou encolhendo. Esse é um indício que leva aos donos da cabana, os sete gigantes mencionados no título.

Essas figuras recebem os mesmos nomes dos anões do conto dos irmãos Grimm (Mestre, Dunga, Soneca, Atchim, Feliz, Zangado e Dengoso), recurso que funciona como uma referência explícita ao conto europeu. A presença dessas personagens remete-nos a outro conto tradicional da cultura ocidental, Cachinhos dourados e os Três Ursos, haja vista que o diálogo entre eles reconstrói o cenário em que os ursos retornam ao seu lar e encontram as coisas reviradas:

_ Ei, alguém comeu do nosso mingau. Tem um prato aqui sem lavar. 
E a minha cama também está desarrumada!

__Alguém andou por aqui e fez bagunça!

_ Isto está parecendo outra história...

_ Seja quem for, é muito mal-educado. Comeu o mingau e nem lavou a louça! (FILHO, p.

12)

Essas falas dos gigantes também fazem recordar a reação dos anões de Branca de Neve ao voltarem da mina e perceberem a presença de uma pessoa estranha. Dessa forma, pode-se afirmar que o conto Pretinha de Neve e os Sete Gigantes absorve e transforma outros textos, revelando-se como uma narrativa intertextual.

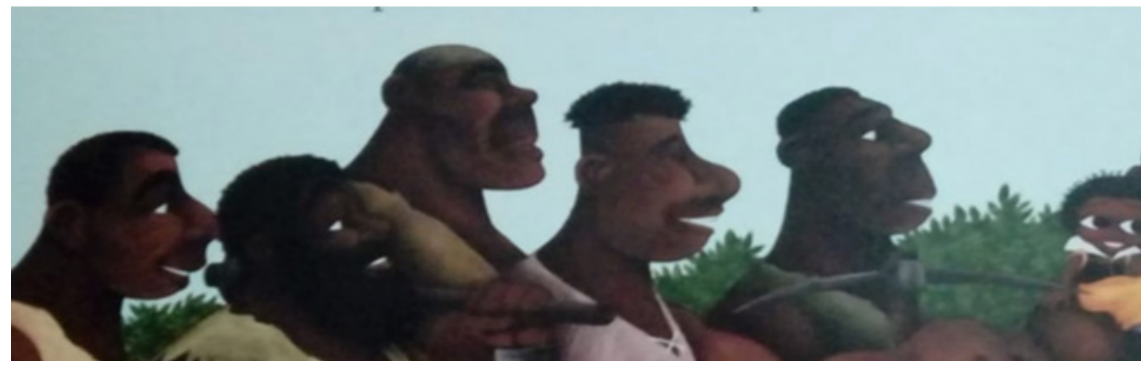

Figura 8 - Os Sete Gigantes cuidam de Pretinha

Fonte: PNSG, p. 13

$\mathrm{O}$ fato de serem apresentados como gigantes atribui às personagens negras certa imponência, já que são apresentadas de forma positiva, o que as reveste de grandiosidade, agregando valores positivos ao imaginário sobre os negros. Assim como os anões - figuras brancas - ajudam Branca de Neve, apresentando-se como seres bons e generosos, os gigantes negros também são inseridos nessa posição de seres que fazem o bem, que ajudam, afastando da personagem negra traços psicológicos que colaboram para a construção de uma valoração depreciativa. Esse aspecto colabora para que o leitor identifique-se com essas personagens, já que nessa fase da formação leitora pode ocorrer tanto a identificação quanto a rejeição com relação às personagens.

Com o passar dos dias, Pretinha adapta-se à vida com os gigantes, como se pode ver:

Ela gostava de passear pela floresta montada ora no ombro de um, ora no de outro. Também se divertia muito brincando com eles de esconde-esconde e, claro, era sempre a última a ser encontrada. Logo se acostumou com a cabana, com o calor, com as árvores e os bichos, e tudo o mais que lá no alto da montanha não existia. (FILHO, p. 14)

Ela agora se mostra uma menina feliz, satisfeita com a liberdade para brincar. Contudo, no 
castelo, sua mãe sentia muitas saudades dela: “- Tacho de cobre, tacho de cobre, existe uma mãe mais preocupada do que eu?" (FILHO, 2013, p.14). Nessa fala da rainha, é notória, mais uma vez, a retomada da fala da madrasta em sua conversa com o espelho, confirmando o caráter paródico da obra, isto é, a retomada de um texto com "a função de problematizar, inverter e questionar até mesmo o modelo literário sobre o qual se estabelece" (ALAVARCE, 2009, p. 59).

Devido a essa saudade que a mãe de Pretinha sentia da menina, o rei acaba indo até a cabana dos gigantes, com o intuito de trazer a garota de volta para o castelo. Observando a caracterização dessa personagem, o leitor é remetido a outra passagem do conto Branca de Neve e os Sete Anões, pois em determinado momento da história a madrasta de Branca também se disfarça para ir à floresta tentar se reaproximar de sua enteada.

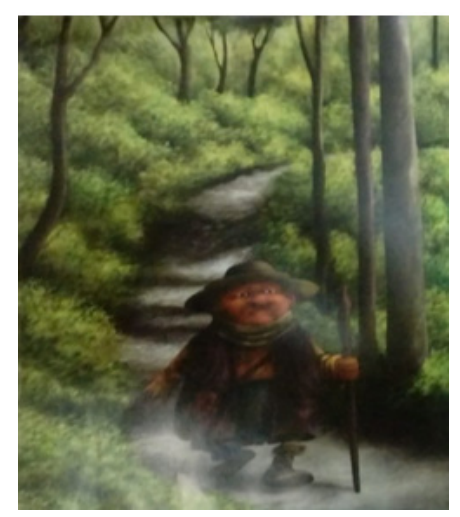

Figura 9 - O rei fantasiado de mendigo

Fonte: PNSG, p. 16

Nesta cena, a fisionomia do rei traz um ar de preocupação que se explica pelo fato de que, enquanto caminhava pela floresta, o padrasto deu-se conta dos motivos que fizeram Pretinha fugir do castelo, provocando uma surpresa para o leitor, pois nesse momento as figuras padrasto e madrasta dos dois contos são delineadas de forma bem distintas, uma vez que passam a assumir posturas diferentes. Isso ocorre porque a madrasta de Branca de Neve, em nenhum momento, se redime de suas maldades, ao passo que o padrasto de Pretinha, mesmo sendo "convencido e mandão", sente falta da menina, quer trazê-la de volta. Essa passagem da narrativa desconstrói o estereótipo atribuído às personagens negras ao longo da literatura brasileira infantojuvenil, segundo a qual "a negritude era associada ao mal e os que faziam mal eram negros" (BROOKSHAW, 1983, p. 13), pois o rei acaba sendo caracterizado como um ser bom. Esse aspecto torna-se evidente na seguinte passagem da narrativa, que versa sobre o momento em que o rei sai do castelo e vai à floresta:

Desceu a montanha. Na verdade, ele estava até achando bom passear um pouco. Há quanto tempo não deixava o seu castelo! Respirou o ar fresco, curtindo aquele calorzinho, que acabou 
por aquecer o seu coração. Percebeu que Pretinha só tinha fugido do castelo porque não se sentia feliz. Afinal, ele era convencido e mandão, a mãe dela estava sempre ocupada e o castelo era mesmo frio à beça. Prometeu a si mesmo que, quando a família estivesse reunida de novo, ele seria um rei diferente, mais atencioso e legal (FILHO, 2013, p. 17).

Além de atencioso e legal, a personagem também é caracterizada como empática, pois acaba colocando-se no lugar de Pretinha e tenta compreendê-la. Outro detalhe que revela sua benevolência é que mesmo levando um alimento encantado para Pretinha - como fez a madrasta de Branca de Neve - seu propósito era distinto. Enquanto a madrasta entrega à princesa europeia uma maçã envenenada, com o intuito de matá-la, ele queria apenas fazer com que a princesa africana dormisse para poder levá-la de volta ao castelo, para isso lhe oferece um doce.

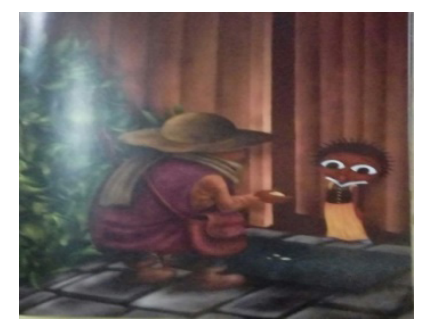

Figura 10 - O rei encontra Pretinha na cabana dos gigantes Fonte: PNSG, p. 18

Nesta passagem da narrativa, ocorre uma inversão de papéis no que diz respeito aos lugares destinados a personagens brancos e negros, pois a madrasta, que é branca, é lembrada como má, ao passo que o rei, que é negro, é bom. Isso é positivo na medida em que oferece ao leitor em formação uma gama variada de representações tanto de brancos quanto de negros, levando a criança ou o jovem a confrontar as representações, a refletir sobre elas e, o mais importante, a romper com as imagens limitadoras acerca da personagem negra. Após esse reencontro da princesa com o rei, os dois fazem as pazes e, em comum acordo com os gigantes, decidem morar na floresta, ao lado dos gigantes:

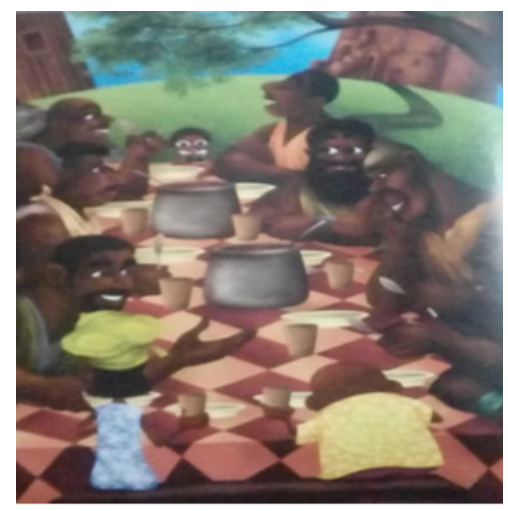

Figura 11 - Todos almoçam juntos para comemorar o novo castelo e a união de Pretinha e sua família Fonte: PNSG, p. 22 
Assim, para terminar a história, os gigantes construíram um bonito castelo para a família real, maior e mais aconchegante. Os novos ares ensolarados fizeram muito bem ao rei, que deixou de ser convencido e mandão [...]. A mãe de Pretinha passou a ser mais atenciosa e a brincar e rir com a filha [...]. Pretinha, por sua vez, se tornou uma menina muito carinhosa com os pais, e viu quanto isso é importante (FILHO, p. 23).

Tanto na figura 11 quanto no fragmento acima, percebe-se que, longe de um final triste, ligado à miséria, a princesa negra tem o direito à felicidade, a viver em um lugar bonito e ao lado de uma família que a ama. Esse quadro é totalmente diferente da trajetória da maioria das personagens negras que povoam a literatura infantojuvenil, pois estas, na maioria das vezes, não têm um final feliz.

\section{Considerações finais}

Em Pretinha de Neve e os Sete Gigantes (2013), percebeu-se a importância da ilustração, uma vez que ela funciona como a responsável por efetivar a presença das personagens negras na narrativa, isto é, por garantir a representatividade negra. No caso específico da princesa, a narrativa promove a imagem de uma princesa que rompe com os moldes eurocêntricos, já que ela é elaborada a partir de traços negros/africanos.

Apesar de ser uma obra que se baseia em moldes europeus, já que é claramente uma paródia de Branca de Neve e os Sete anões, a obra introduz figuras negras que compõem uma realeza africana, o que contribui para a construção de imagens positivas sobre o negro, indo de encontro às representações negativas das quais este tem sido alvo ao longo da história da literatura infantojuvenil.

\section{Referências}

ALAVARCE, Camila da Silva. A ironia e sua refrações: um estudo sobre a dissonância na paródia e no riso. 2008. 212 f. Tese (doutorado) - Universidade Estadual Paulista, Faculdade de Ciências e Letras de Araraquara, 2008.

Disponível em: < $\underline{\text { http://hdl.handle.net/11449/102407> }}$. Acesso em: 20 Abr. 2019.

BERTH, Joice. O que é empoderamento? Belo Horizonte: Letramento, 2018.

BROOKSHAW, David. Raça e cor na literatura brasileira. Tradução: Marta Kirst. Porto Alegre: Mercado Aberto, 1983. 
COELHO, Nelly Novaes. Literatura infantil:história, teoria, análise. 4. ed. São Paulo: Quíron, 1987.

CORREIA, Rita Mira. O arquétipo da princesa na construção social da feminilidade. Universidade Nova de Lisboa. Lisboa, 2010. Disponível em: <https://run.unl.pt/bitstream/10362/5980/1/Tese.pdf> Acesso em: 20 Abr. 2020.

FILHO, Rubem. Pretinha de Neve e os Sete Gigantes. 4. ed. São Paulo: Paulinas, 2013.

KAERCHER, Gládis; DALLA ZEN, Maria Isabel Habckost.Leituras de crianças sobre a diferença étnico-racial. In: SILVEIRA, Rosa Hessel(org.). A diferença na literatura infantil:narrativas e leituras. São Paulo: Moderna, 2012, p.185-205.

LAJOLO, Marisa; ZILBERMAN, Regina. Da matriz europeia ao folclore brasileiro. In: Literatura infantil brasileira:histórias e histórias. 6. ed. São Paulo: Ática, 2007, p. 68-83.

LIMA, Heloisa Pires. A origem africana para o imaginário infantil ou juvenil: uma obra em muitas histórias. In: ALMEIDA, Dalva Martins de; SILVA, Gislene Maria Barral Lima Felipe da; NAKAGONE, Patricia Trindade (orgs.). Literatura e infância:travessias. Araraquara: Letraria, 2018, p. 30-52.

LIMA, Heloísa Pires. De personagem a editor: vozes negrasna literatura infanto-juvenil. Via Atlântica, São Paulo, dez. 2010. Disponível em: <http://www.revistas.usp.br/viaatlantica/article/view/50739/54845> Acesso em: 12 Set. 2018.

LIMA, Heloísa Pires. Personagens negros: um breve perfil na literatura infantojuvenil. In: MUNANGA, Kabengele (org.). Superando o racismo na escola. 2. ed. Brasília: Ministério da educação, Secretariade educação continuada, alfabetização e diversidade, 2005, p.101-115.

LINDEN, Sophie Van Der. Para ler o livro ilustrado. São Paulo: Cosac Naify, 2011.

OLIVA, Anderson Ribeiro. A Invenção da África no Brasil: os africanos diante dos imaginários e discursos brasileiros dos séculos XIX e XX. Revista África e Africanidades, Fev. 2009. Disponível em: <http://www.africaeafricanidades. com.br/documentos/A_invencao_da_Africa_no_Brasil.pdf> Acesso em: 16 Jun. 2018.

OLIVEIRA, Maria Anória de J. Personagens negros na literatura infanto-juvenil: percorrendo os tênues fios de suas tessituras. In: JOACHIM, Sébastien (org.). II Cidadania Cultural:diversidade cultural, linguagens e identidades. Campina Grande: Editora dos organizadores, 2007, p. 245-261. 
REIS, Carlos. Pessoas de livro: estudos sobre a personagem. 3. ed. Coimbra: Imprensa Universidade de Coimbra, 2018.

ROCHA, Sueli de O. São outras as nossas princesas.Leituras compartilhadas, Londrina, mar. 2009. Disponível em: $<$ http://www.uel.br/neaa/sites/default /files/ebooks/PRINCESAS\%20AFRICANAS\%20\%20LIVRS.pdf $>$ Acesso em: 21 Out. 2018.

SAMOYAULT, Tiphaine. A intertextualidade. São Paulo: Aderaldo \&Rothschild, 2008.

SOUSA, Andréia Lisboa de. Nas malhas das imagens e nas trilhas da resistência: heroínas negras de ontem e de hoje. Leituras compartilhadas, Londrina, mar. 2009. Disponível em: <http://www.uel.br/neaa/sites/default/files/ebo oks/ PRINCESAS\%20AFRICANAS\%20-\%20LIVROS.pdf> Acesso em: 21 Out. 2018.

WUNENBURGER, Jean-Jacques. O imaginário. São Paulo: Loyola, 2007. 